\title{
The City as Laboratory and the Urban-Rural Divide
}

The Revival of Private Property and its Limits in Post-Mao China

Tim Murphy and Ting $\mathrm{Xu}$

\section{(2) OpenEdition}

\section{Journals}

Electronic version

URL: http://journals.openedition.org/chinaperspectives/4733

DOI: $10.4000 /$ chinaperspectives. 4733

ISSN: 1996-4617

\section{Publisher}

Centre d'étude français sur la Chine contemporaine

\section{Printed version}

Date of publication: 1 December 2008

Number of pages: $26-34$

ISSN: 2070-3449

Electronic reference

Tim Murphy and Ting Xu, « The City as Laboratory and the Urban-Rural Divide », China Perspectives [Online], 2008/4 | 2008, Online since 01 December 2011, connection on 28 October 2019. URL : http:// journals.openedition.org/chinaperspectives/4733; DOI : 10.4000/chinaperspectives.4733

(C) All rights reserved 
(1)

The City as Laboratory and

the Urban-Rural Divide

The Revival of Private Property and its Limits in Post-Mao China

TING XU AND TIM MURPHY

This paper focuses on the revival of private property and its limits in urban China. It explores the emergence of urban property markets; urban property-holding in relation to the complexity of urban governance; "minor property rights apartments" that form a de facto real estate market and cross over the urban-rural divide; the "grey areas" of blurring legal and administrative boundaries in modern China; and recent changes to the rural land system and the rural-urban divide. The conclusion flags the theme of the city as laboratory with regard to the blurring legal and governmental urban-rural distinction.

\section{Introduction}

E xamination of the transformation of urban China tends to rely on dichotomies such as tradition vs. modernity, past vs. future, collectivism vs. individualism, public (gong) vs. private (si), and rural vs. urban. This paper tries to sidestep these distinctions by looking at the revival of private property and its limits in urban China.

In the governmental scheme of traditional China no clear distinction was drawn between cities and the countryside. (I) Urbanisation and the formation of "modern" cities in Republican China undermined such uniformity and gave birth to the urban-rural divide. The gap between the urban and the rural has become even wider in the post-1949 era. Mao's revolutionary rhetoric was pro-village and anti-city, because the rural area in Southern China (e.g., Jiangxi and Fujian) was his revolutionary base. But in the post-1949 era, industrialisation was set, in emulation of the USSR, as the priority in state policy and state-building. The development of the city thereafter proceeded at the expense of the countryside, and the household registration system (huji zhidu) ${ }^{(2)}$ made, at least in theory, the gap between the rural and the urban even wider.

Yet in post-Deng China, as cities expand into their rural peripheries, legal distinctions between urban and rural become blurred, and in due course the boundaries of cities and the legal regimes applicable in them will need to be redefined. ${ }^{(3)}$ For example, in the rural area, a de facto real estate market is emerging with affordable prices under the label of "minor property rights" (xiaochanquan) or "township property rights" (xiangchanquan). This invites an analysis of how the boundaries between the urban and the rural and between public property and private property are being drawn in modern China.

\section{The emergence of urban property markets in China}

The advent of socialist rule in 1949 brought significant changes to the official conception of property. Between 1956 and 1978, "the private" was deemed to be evil and virtually abolished. ${ }^{(4)}$ Since the beginning of market reform, the

1. On rural-urban uniformity in traditional China see e.g., F. W. Mote, "The Transformation of Nanjing, 1350-1400," in G. William Skinner (ed.), The City in Late Imperial China, Stanford, Stanford University Press, 1977, pp. 101-154.

2. The rigid household system was established in 1958. Mobility was prohibited, especially the mobility from the rural to the urban areas.

3. It is clear to most observers that much of China's rural economy relies, partly or largely, depending on the region, on remittances from family members who work legally or illegally in urban centres.

4. Private ownership was not formally abolished in 1949, and a mixed economy was adopted between 1949 and 1956 as a prelude to nationalisation of private capital. Whether nor not a complete system of public ownership was established is unclear. For example, Article 11 of the 1954 Constitution recognised private property: "the State protects the right of citizens to own lawfully-earned incomes, savings, houses and other means of life." Article 12 of the 1954 Constitution provides: "the State protects the right of citizens to inherit private property according to law." The content of Article 11 of the 1954 Constitution was restated in Article 9 of the 1975 Constitution, but "the right to inherit private property" was abandoned in the 1975 Constitution. 
private sector has re-emerged and the status of private property has gradually been rehabilitated. Legislation acknowledged this rehabilitation. In the post-1978 era, the long process of drafting a new property law (wuquanfa) for China took place against the backdrop of the development of the private sector and legislating to promote a "market economy." (5) The 1988 Constitution was amended to allow the transfer of land use rights. ${ }^{(6)}$ The Provisional Regulation on the Grant and Transfer of Use Rights in Urban Land (1990) ${ }^{(7)}$ paved the way for the commodification of urban land. The Constitution was changed in 2004, and the Property Law (2007) provided equal protection for public and private property for the first time since $1949{ }^{(8)}$

Urban land, one of the most important state-owned assets, became leaseable and transferable in the late 1980s through the mechanism of the land use rights (LUR) system. ${ }^{\left({ }^{9}\right)}$ The LUR system - in emulation of "legacy" leasehold in Hong Kong - was first developed to attract foreign direct investment (FDI) in order to fund the construction of Special Economic Zones (SEZs) such as Shenzhen. ${ }^{(10)}$ The lease and transfer of LURs have given rise to the emergence of an urban property market, which is regarded as one of the most important indications of a revival of private property in China.

In parallel with changes to the urban land system, the urban housing sector has also involved transformations: when the PRC was established in 1949, private ownership was not abolished immediately; in the cities, people owned their houses. The 1954 Constitution acknowledged the status of private ownership. However, after the "socialist transformation" (shehuizhuyi gaizao) in 1956, the housing market was gradually abolished. (11) In the 1980s there was a massive construction of public housing, and the dominant form was public rental. ${ }^{(12)}$ The housing was built on allocated stateowned land, and work units (danwei) or urban Real Estate Administration Bureaux represented the de facto "public" owners. In the late 1980s, based on the LUR system, urban households in China were given the opportunity to purchase their flats/houses for the first time. ${ }^{(13)}$ In March 1998, Premier Zhu Rongji introduced a package of reforms that included terminating housing provision and allocation by work units. ${ }^{(14)}$ The subsequent direction of housing reform has been to let individuals purchase houses, and the private housing market has since flourished. From 2000, housing began to be commodified (shangpin hua) in China. ${ }^{(15)} \mathrm{As}$ Huang Youqin points out, a class of homeowners began to emerge. ${ }^{(16)}$ Yet urban residents' land use rights are vulnerable property rights. ${ }^{(17)}$

\section{Property-holding and the complexity of urban governance}

The lease of state-owned land has been legalised since the promulgation of the 1986 Land Administration Law (LAL). In April 1988 the Constitution was also amended

5. See Donald C. Clarke, "Legislating for a Market Economy in China," The China Quarterly, no. 191,2007 , pp. 567-585.

6. See Article 10 of the Constitution (1988). But this Article does not specify the mechanism for land use rights transfer.

7. Chengzhen guoyou tudi shiyongquan churang he zhuanrang zanxing tiaoli, enacted by the State Council, in force in May 1990.

8. The Property Law (wuquanfa), Article 4.

9. The duration of an LUR varies from 40 to 70 years, depending on the types of land use, for example, 40 years for commercial purpose, 50 years for industrial purpose, and 70 years for residential purpose. In order to acquire LURs, property developers have to develop good relationships with local governments, and so more rent-seeking opportunities have been generated.

10. Leasing the land in return for cash was the solution to the funding shortage in constructing Shenzhen, but leasing publicly-owned land to "capitalists" was regarded as a betrayal of socialist principles. In order to justify the LUR system, cadres and policy makers found a quotation in Lenin's The State and Revolution in which Lenin cited Engels' The Housing Question (1872): "The 'working people' remain the collective owners of the houses, factories and instruments of labour, and will hardly permit their use, at least during a transitional period, by individuals or associations without compensation for the cost. In the same way, the abolition of property in land is not the abolition of ground rent but its transfer, if in a modified form, to society." See V. I. Lenin, The State and Revolution: The Marxist Theory of the State and the Tasks of the Proletariat in the Revolution, Moscow, Progress Publishers, $1949[1917])$, p. 57. It is said that at that time every cadre in Shenzhen could recite this quotation. On this see e.g., Wu Xiaobo, Jidang sanshinian: Zhongguo qiye 1978-2008 (Chinese Business 1978-2008, Vol.1), Beijing, Zhongxin chubanshe, 2008, pp. 52-53.

11. In the late 1980 s, state policies permitted the original owners and their heirs to claim partial property rights over houses that were once managed by the state, but even today there is not a good mechanism for the original owners and their heirs to claim complete property rights.

12. See Youqin Huang, "The Road to Homeownership: A Longitudinal Analysis of Tenure Transition in Urban China (1949-1994)," International Journal of Urban and Regional Research, Vol. 28, no. 4, 2004, p. 778.

13. At that time, there was a need to stimulate the economy, and the real estate market has served as such an engine since then.

14. During the course of the housing reform until 1998, a new kind of housing (the so-called "reform housing," fanggaifang) emerged. Public housing had been sold, mostly to sitting tenants, that is, employees of work units, at discounted prices. Because this housing was built on allocated state-owned land, and LUR transfer fees were not paid, buyers just "owned" the houses themselves. When resale becomes necessary, the work unit had the right of first refusal, and the owner must hand back to the land management bureaux a proportion of the profits made as LUR transfer fees. On this see Ya Ping Wang, "Urban Housing Reform and Finance in China: A Case Study of Beijing," Urban Affairs Review, Vol. 36 , no. 5,2001 , p. 625 . According to the new housing policies introduced in 1998, employees should go to the real estate market to purchase their housing; work units should not be involved directly in housing construction and provision, but could provide housing subsidies for their employees. This new policy was in response to the Asian financial crisis, and the government strategy at that time was to expand internal consumption. On Zhu Rongji's reform package see e.g., David Zweig, "China's Stalled 'Fifth Wave': Zhu Rongji's Reform Package of 1998-2000," Asian Survey, Vol. 41, no. 2, 2001, pp. 231-247.

15. On housing commodification see e.g., Min Zhou and John R. Logan, "Market Transition and the Commodification of Housing in Urban China," in John R. Logan (ed.) The New Chinese City: Globalization and Market Reform, Oxford, Blackwell Publishers, 2002, pp. 137-152.

16. See Youqin Huang, "The Road to Homeownership," art. cit., p.774.

17. Although urban land has been commodified, it is far from being privatised. LURs are vulnerable to compulsory reclamation by the state, and ordinary owners do not have security for their properties. House demolition (chai qian) in urban China has generated public riots in recent years. House demolition is, in practice, at the discretion of local governments, and people usually get compensation below the market price. 
LURs between primary and secondary property markets means that local governments can acquire LURs at a low price and sell them to property developers at a high price. As analysed above, when the LUR system was introduced, it was hoped that the value of land would be reflected properly in the market. However, a high proportion of land allocation is still carried out on an administrative basis, ${ }^{(29)}$ and only a small portion of land is leased by the state to the users through paid transfer of use rights. ${ }^{(30)}$ This means that local governments can monopolise the supply of LURs. ${ }^{(31)}$ The 1998 LAL attempted to remove authority to approve land requisitions from local governments below the provincial level. However, local governments often exceed their authority to approve land use. ${ }^{(32)}$ Numerous public and private brokers with links to state agencies that have the power to allocate and manage land have arisen to pursue rents generated from the gap that exists between the primary and secondary property markets.

The black market is also manifested in the role of rapidly expanding "private" property developers. ${ }^{(3)}$ It is becoming increasingly common for party/governmental officials to set up private businesses by various informal means. ${ }^{(34)}$ Commodification of the public housing provision system has been one of the most important aspects of economic reform. But is it the same as privatisation? The liberal assumption of the distinction between public and private cannot easily be transposed to the Chinese context. The public and the private are intertwined, given the complexity of governance in China. Land-related corruption or rent-seeking is usually associated with land approval and bidding processes. ${ }^{(35)}$ The party-state defines, regulates, and directly participates in the market. ${ }^{(36)}$

\section{"Minor property rights"}

\section{apartments - a de facto real} estate market and a grass-roots initiative

Dual land ownership ${ }^{(37)}$ and the dual land allocation system explain the high price of real estate in urban China. While the price in the urban property market keeps soaring, ${ }^{(38)}$ "minor property rights" apartments are emerging in rural areas. This kind of apartment is built on rural residential plots (zhaiji di). The buyers of these properties cannot obtain property right certificates (chanquan zheng), because the premises are built on collectively owned land that is reserved for residential use by farmers, and cannot be commodified in the real estate market according to the Land Administration Law (2004) and the Property Law (2007). Yet the market for "minor property rights" apartments flourishes, because prices are low compared with those in the urban property market.

The legality of "minor property rights" apartments has been subject to investigation and has even been declared illegal. For example, in the 17th National Land Day campaign, ${ }^{\left({ }^{(3)}\right.}$ jointly sponsored by the Ministry of Land and Resources and the Beijing municipal government, one of the issues that seized people's attention was concern about "minor property rights" apartments. The Ministry of Construction warned purchasers of the risks involved in buying these apartments. By contrast, township governments clearly acquiesced in the development of "minor property rights" apartments, ${ }^{(40)}$ which is another illustration of the complex relationship between the central and local governments. On 11 December 2007, the State Council declared that "city and township residents should not purchase 'minor property rights' apartments in the rural area." ${ }^{(4)}$ Minor property rights apartments

29. For example, Huabo tudi shiyongquan zanxing tiaoli (Provisional Regulations on Administratively-Allocated Land Use Rights) (1992), enacted by the State Land Administration Bureau on 24 February 1992; in effect on 24 February 1992.

30. See Anthony Gar-on Yeh, "The Dual Land Market and Urban Development in China," in Chengri Ding and Yan Song (eds.), Emerging land and housing markets in China, op. cit., p. 40.

31. See Anthony Gar On Yeh, "Dual Land Market and Internal Spatial Structure of Chinese Cities," in Laurence J. C. Mar and Fulong Wu (eds.), Restructuring the Chinese City: Changing Society, Economy and Space, New York, NY, Routledge, 2005, p. 60.

32. See Xie, Parsa, and Redding, "The Emergence of the Urban Land Market in China," art cit., p. 1392.

33. There are three kinds of property developers in today's China: state enterprises, private companies, and foreign companies (there have been more restrictions on foreign property developing companies since 2006). See Walker and Buck, "The Chinese Road," art. cit., p. 48.

34. See Gordon White, Jude Howell, and Xiaoyuan Shang, In Search of Civil Society: Market Reform and Social Changes in Contemporary China, New York, Clarendon Press, 1996, p. 199.

35. See e.g., Ho and Lin, "Emerging Land Markets in Rural and Urban China," art. cit;; Walker and Buck, "The Chinese Road," art. cit.

36. Paid transfer of LURs has become the basis for partnership between the government and the private sector in China. See e.g., Shenjing He and Fulong Wu, "Property-Led Redevelopment in Post Reform China: A Case Study of Xintiandi Redevelopment Project in Shanghai," Journal of Urban Affairs, Vol. 27, no. 1, 2005, pp. 1-23; On "a government for capital," see Walker and Buck, "The Chinese Road," art. cit., p. 61.

37. That is, urban land is owned by the state, while rural land is owned by collectives.

38. It should be pointed out that bubbles in the property market have now emerged, as seen in the recent plummeting house prices in Shenzhen in 2008.

39. The 17th National Land Day was on 25 June 2007.

40. Township governments do not have the authority to grant land use rights, therefore they cannot profit from collecting LUR transfer fees. Township governments could gain more profit from making use of grey areas such as "minor property rights apartments," and competing for more income from land with the superior governments. On the role of township governments, see e.g., You-tien Hsing, "Broking Power and Property in China's Townships," art. cit., pp. 103-124.

41. See Wu Jiandong, "Xiaochanquan fang bude mai bu yiweizhe bujiejue wenti" (A ban on "minor property rights" apartments does not mean that the problem will not be resolved), Nanfang Zhoumo (Southern Weekend), 20 December 2007. In http://bj.house.sina.com.cn/dcpl/200712-20/1417230527.html (last visited 16 October 2008). 
in some areas were demolished by force. ${ }^{(42)}$ However, these counter-measures have not made "minor property rights" apartments disappear. So what will be the fate of "minor property rights" apartments? This question will be further discussed in Section VI.

"Minor property rights" apartments have existed "underground" for more than 10 years. The central government has issued various regulations concerning them, which suggest some uncertainty about how best to deal with them. ${ }^{(43)}$ Chapter 13 of the property law deals with the LURs of rural residential plots, but it is unclear about their transfer. Therefore, the transfer and sale of rural residential plots and the sale and transfer of LURs for construction purposes by farmers (if not reclaimed by the state first) are still banned. Despite this uncertainty, various kinds of experiments have been conducted by localities. In 1992, a farmland shareholding system (tudi gufen zhi) was tested in Nanhai, a countylevel city in Guangdong Province. Land use rights of individual farmers were collectivised by "natural" villages and then by the administrative village to which these villages belonged. The value of farmland was appraised and divided into shares. A shareholding cooperative was thus formed. The farmland was rented by the cooperative for industrial purposes. Farmers could enjoy the profits of industrialisation according to the shares they had. In this case, the purpose of use of agricultural land had been changed through the circulation of land use rights. This system was called the Nanhai model (nanhai moshi). In 1995, Suzhou in Jiangsu Province was the first to approve the transfer of LURs for construction purposes. Similar experiments were subsequently conducted at Huzhou in Zhejiang Province in 1997, and at Wuhu in Anhui Province in 2000. ${ }^{(4)}$ The practice in Guangdong is notable. In 2005, the Guangdong provincial government announced the promulgation of a law entitled "Guangdong Regulations for the Transfer of Land Use Rights of Collectively Owned Land for Construction Purposes." This was the first time in China that LURs for construction purposes were legalised via provincial-level legislation. It was also a sign of the marketisation of LURs of rural collective construction land. In 2007, Guangdong introduced further reforms permitting rural residential plots to be transferred in the market. ${ }^{(45)}$

Further local reforms on the rural LURs focus on allowing farmers to contribute rural land contractual management rights as shares to enterprises or joint ventures. The Land Contracting Law and the LAL conflict on this point. ${ }^{(46)}$ Despite these contradictory laws and regulations, on 1 July 2007, Chongqing allowed farmers to contribute LURs to joint enterprises or joint ventures as shares, provided that the purpose of use of arable land is not changed. Shanghai's reform is even more extensive: on 2 July 2007, the Shanghai Industrial and Commercial Administration $\mathrm{Bu}-$ reau allowed farmers to use and rent their residential plots to run village inns, or so-called "family farms," which exceeds the limits within which the use purpose of arable land cannot be changed and paves the way for farmers to participate in urbanisation and industrialisation directly. ${ }^{(47)}$ Yet these reforms are clearly against Articles 60 and 63 of the LAL.

\section{Grey areas: Blurring legal and administrative boundaries in modern China}

Thirty years after the re-admission of private property into the Chinese lexicon in the name of economic reform and opening-up, ${ }^{(48)}$ real estate has become a far from obscure object of desire in China. Chinese dream of owning their homes and invest most of their savings in this project. ${ }^{(49)}$ But to what extent do people own their flats or houses? What does ownership mean? And why is ownership important? Is it important because it is closely linked to status, privi-

42. See Ding Rui, "Guotu bu: yanzhong weigui de xiaochanquan fang jiangbei chaichu" (The Ministry of Land Resources: "Minor property rights" apartments that contravene the regulations will be demolished), in Beijing Shangbao (Beijing Business Today), 13 December 2007. In http://news.hexun.com/2007-12-13/102266679.html (last visited 20 0ctober 2008)

43. In terms of the central government's policy, in 2004, the State Council published "On deepening the reform and tightening the land administration" (2004, No. 28), which stressed that LURs of collectively owned land could be transferred according to law however, it did not go beyond the limits provided by the LAL and the Guarantee Law (danbao fa). The newly published property law is still within the framework of the LAL. See Article 153 of Property law; Article 62 of the LAL.

44. See Chen Xu, "Xiaochanquanfang shi gaige chiyi bujue de chengben" (Minor property rights apartments are the cost of the hesitation of reforms), Oriental Morning Post, 10 July 2007

45. See Tan Jialong, "Guangdong nirang nongcun zhaijidi shangshi liuzhuan" (Guangdong plans to permit rural residential plots to be transferred in the market), Xinhua wang (Xinhua Net), 26 June 2007, http://politics.people.com.cn/GB/14562/5912261.html (last visited 4 September 2008).

46. Article 42 of the Land Contracting Law allows farmers to contribute rural land contractual management rights as shares; according to Article 60 of the LAL, farmers cannot contribute LURs to joint enterprises or joint ventures as investments, or assign LURs to township enterprises without approval from the government at or above county levels.

47. See "Shanghai: Nongmin zhaijidi ke ban 'nongjiale'" (Shanghai: Rural residential plots could run "family farms"), Xin nongcun shangbao (New Countryside Commerce), in http://xncsb.mofcom.gov.cn/listx.asp?id=112335 (last visited 3 0ctober 2008).

48. That is, economic growth and attracting Foreign Direct Investment (FDI).

49. More Chinese households put their money in assets such as stocks and the real estate market; see e.g., Olivia Chung, "Chinese Favor Bourses, Bullion over Banks," Asia Times (online), 25 October 2007. Because of the uneven development of the stock market, investing in the real estate market has become the first choice. 
lege, or wealth? Who has the power to define ownership? And how do they draw the boundaries between the public and the private?

Law can provide some of the answers to these questions. Yet many uncertainties over property law itself remain - for example, whether ownership should be formulated as an economic institution (jingji zhidu) or a social institution (shehui zhidu).

Furthermore, ownership defined in law and ownership as understood and practised in society often diverge, and property lawmaking often lags behind social change. ${ }^{(50)}$ Rather than using a much broader concept of property rights (caichan quan), wuquan is defined in the 2007 Property Law, and it only refers to property rights over tangible things. ${ }^{(51)}$ Specifically speaking, wuquan means the exclusive rights that directly control specific things. Wuquan includes ownership (suoyou quan), usufructuary (yongyi wuquan), and security rights (danbao wuquan). ${ }^{(52)}$ Usufruct is the legal right to possess, use, and benefit from property that belongs to another person. In terms of usufruct, the decentralised interests pertaining to land are mainly categorised as "land use rights" (tudi shiyong quan) of state-owned land (mostly urban land), (53) "contractual management rights" (chengbao jingyingquan) of collectively owned rural land, ${ }^{(54)}$ as well as other rural land use rights including those of residential plots and those for construction purposes. Although state ownership of urban land may be straightforward in the law, whether the central government or local governments can represent the state as the owner is debatable. Moreover, collective ownership of rural land is fragile, and various kinds of land use rights are also ambiguous.

There exist variations, tensions, and intricacies in terms of different forms of de facto ownership in practice. Meanwhile the boundaries between public property and private property are blurred, and property rights are fragmented. For example, state-owned assets have been transferred to those who hold political power; local governments have de facto control over both collectively-owned rural land and urban land; home buyers have ownership over buildings or parts of buildings but not over the land on which their flats and houses are built. The post- 1978 process of property lawmaking is a move to "propertise" the fragmented rights that emerged in the process of economic reform; however, there are still residual categories that are difficult to define or "legalise" in a systematic way. ${ }^{(5)}$

State ownership was based on the Soviet version of state ownership - the factory model. ${ }^{(56)}$ But this did not overcome the scarcity of resources; centrally-planned allocation was inefficient, and was gradually converted into allocation of resources through the market. However, in the meantime, policy makers had to make sure that state-owned enterprises were able to acquire resources and did not lose the competition with private enterprises; a dual-track price system thus emerged in 1985. The state retained control of the prices of goods distributed through administrative channels in accordance with the plan, while the market would decide the prices of goods produced outside the plan. ${ }^{(57)}$ The distinction between "inside the system" (tizhinei) and "outside the system" (tizhiwai) emerged, although it is hard to give a specific definition of this distinction. "Inside the system" could mean inside the plan or having easy access to resources. Those with the political influence to gain access to goods (people inside the system) bought goods at low state-set prices that could vary across and within provinces and sold those goods at higher prices, and thus made enormous profits. Resources are transferred from insiders to outsiders by insider privileges. Great profits can be made. This phenomenon is termed guandao.

Economic reform has seen the selective re-admission of private property into the socio-economic framework. For example, the 1982 Constitution recognised the "individual economy" of urban and rural working people (geti jingji) ${ }^{(58)}$ as a "complement" (buchong) to the socialist public economy (Article 11). The 1988 amendment allowed the private

50. It should be remembered that China may not be so different from some western societies like the UK or the USA in this respect. The "sub-prime" crisis is a reminder of the nature and underpinnings of home ownership in the West.

51. An important aspect of the English approach of thinking about property is the distinction between rights to land and rights to other things, or between real and personal property (including tangibles and intangibles). See W. T. Murphy, Simon Roberts, and Tatiana Flessas, Understanding Property Law 4ed. London, Sweet \& Maxwell, 2004, p. 56. Chinese property law makes a distinction between immoveable (bu dongchan) and moveable property (dongchan). See Article 2 of the Property Law (2007). But intangibles, like debts, patents, copyright, and trademarks, are not subject to Chinese property law, nor are shares in a limited company.

52. The Property Law (2007), Article 2.

53. The Constitution Article 10, (1982, amended in 1988, 1993, 1999, 2004).

54. The General Principles of the Civil Law (GPCL) (1986), Article 80.

55. For example, "minor property rights" apartments built on collectively-owned rural land

56. That is, socialisation of the organisation of the activity or process and the non-separation of home and work embedded in the total institution cradle-to-grave theory of the danwei. For the model, see especially V. I. Lenin, The State and Revolution: The Marxist Theory of the State and the Tasks of the Proletariat in the Revolution, op.cit..

57. On the dual-track price system, see Shahid Yusuf, Kaoru Nabeshima, and Dwight $\mathrm{H}$ Perkins, Under New Ownership: Privatizing China's State-Owned Enterprises, Washington, World Bank, 2006, p. 61; Andrew H. Wedeman, From Mao to Market: Rent Seeking, Local Protectionism, and Marketization in China, Cambridge, Cambridge University Press, 2003

58. That is, economic activities by self-employed individual entrepreneurs with fewer than eight employers. 
economy (siying jingji) to exist and develop within the limits prescribed by law (Article 11). The 1985-1989 stage also saw the rise of privately run and "red hat" enterprises (hongmaozi qiye), ${ }^{(59)}$ which were established under the labels of SOEs or collective enterprises to disguise their private nature. After the "southern tour" of Deng Xiaoping in 1992, private enterprises flourished nationwide, including taking off the hats of many "red-hat enterprises." ${ }^{(60)}$ Since the corporatisation programme (i.e., the modern enterprise system initiated in 1994), the focus of SOE reform has shifted from delegation of decision-making authority to corporate governance and ownership. The $15^{\text {th }}$ National Congress of the CCP in 1997 declared further reform of ownership. In his report to that Congress, Jiang Zemin eulogised "grasping the large and freeing the small" (zhuada fangxiao), and this was endorsed as the central economic reform strategy. Small and medium-sized enterprises were to be sold to private owners.

Yet as more and more "rents" have been "privatised," the control of public assets has been gradually transferred to the persons or privileged groups who hold political power. In the era of fiscal and political decentralisation (from 1994 onwards in particular), the quasi-federal character of local governments gives them more power to control and allocate resources, and the identity of the owner(s) of public assets has become even more ambiguous. In terms of collective ownership over rural land, local governments and rent-seeking local officials operate as de facto owners, and farmers are excluded.

The result is that today there is often a gap between ownership defined in the law and ownership as understood and practised in society. Political elites define the conception of ownership and the distinction between public property and private property in law. These conceptions and distinctions were and are manifested in Mao's revolutionary rhetoric, as well as in Deng's reform rhetoric. They served and still serve for the purposes of rulership and governance. The elites shift, the need for governance shifts, and the conception of ownership and the distinction between the public and the private change with these shifts. In contemporary China, there is a clear distinction between public property and private property in law, but the boundaries between the public and the private in reality are blurred. What is specific here (although not unique to China) is the potential for a large "gap" to emerge between legal stipulations and socio-economic practices, a gap that is quickly being filled by market-watchers or "entrepreneurs."

\section{New changes to the rural land system and the rural-urban divide}

As we were completing this paper, the third Plenum of the $17^{\text {th }}$ CCP Central Committee (hereinafter the Plenum) was held between 9 and 12 October 2008. The Plenum has set a new round of rural reforms in motion, and has brought new changes to rural land use rights and the rural-urban divide. Here, it is necessary to analyse these new changes and their implications.

There are several important aims in the decision (jueding) ${ }^{(6)}$ of the Plenum published on 19 October 2008 (hereinafter the decision). First, it confirms that contractual management rights of rural land will remain unchanged and stable for a long period (baochi wending bing changjiu bubian). The decision also permits various means of contractual management rights circulation (tudi chengbao jingyingquan liuzhuan), including subcontracting (zhuangbao), leasing (chuzu), exchanging (huhuan), transferring (zhuanrang), and shareholding cooperatives (gufen hezuo). ${ }^{(2)}$ This decision emphasises that circulation of contractual management rights should not change the nature of rural land ownership and the agricultural purpose of land use. The decision retains the provisions as set in the Land Contracting Law (2002) and the Land Administration Law (2004). ${ }^{(63)}$

Secondly, the decision aims to improve the system of rural residential plots, tighten the management of residential plots, and protect farmers' usufructuary rights. Although some people claim that the decision has important implications for the possibility of legalising "minor property rights" apartments, ${ }^{(64)}$ the stress on farmers' usufructuary rights in this decision is ambiguous. Usufruct is a lesser property right than ownership, and it does not include the right to dispose of the property. Thus, the decision has not granted farmers the

59. See Clarke, "Legislating for a Market Economy in China," art. cit., p. 569.

60. See e.g., Bruce J. Dickson, Red Capitalists in China: The Chinese Communist Party, Private Entrepreneurs, and Political Change, Cambridge, Cambridge University Press, 2002.

61. "Zhonggong zhongyang guanyu tuijin nongcun gaige fazhan ruogan zhongda wenti de jueding" (The decision of the CCP Central Committee on several crucial issues regarding rural reform and development), available in http://politics.people.com.cn/ $\mathrm{GB} / 1026 / 8194064$.html (last visited 19 October 2008).

62. Article 32 of Land Contracting Law (2002) already provides that "contractual management rights obtained through household contract may, according to law, be circulated by subcontracting, leasing, exchanging and transferring or other means."

63. See this prohibition of changing agricultural purposes in contractual management rights circulation in Clause 2 of Article 33 in the Land Contracting Law (2002).

64. Jia Huajie, "Xiao chanquan fang dengdai diebian" ("Minor property rights" apartments are waiting for approval), in <http://news.sohu.com/20081010/n259947051.shtml> (last visited 19 0ctober 2008). 
right to dispose of their residential plots freely such as by selling them as "minor property rights" apartments. From this perspective, the decision still limits the circulation of residential plots. ${ }^{(6)}$

The third aim is to reform the system of land acquisition and land use rights requisition. The decision emphasises that using rural land for construction purposes should clearly define whether it is for the "public interest" or profit-seeking. The decision also calls for reducing the scope of land acquisition and improving the system of compensation.

Lastly, the decision treats rural and urban land use rights for construction purposes (jianshe yongdi shiyongquan) equally, and aims to gradually set up a unified market for circulation of such land use rights. Apart from rural land use rights for construction purposes, the decision also approves the use of collectively owned rural land in for-profit projects.

The reform is designed to boost rural income and rural productivity, stimulate rural consumption, and diminish the rural-urban divide by gradually abandoning the household registration system. This reform is also regarded as a prelude to the reform of the rural financial system, by, for example, providing loans for farmers. The reform will also bring changes to the relation between the state and farmers, as well as adjustment of interests gained by different groups throughout the economic reform commenced in 1978. However, the effect of the new measures regarding the circulation of contractual management rights is debatable. Some worry that, without a functioning social security system, loosening the control over the circulation of rural land use rights may make farmers transfer contractual management rights cheaply to big agricultural conglomerates. The number of landless farmers could increase, and a new form of inequality could thus emerge.

Clarifying the land rights of farmers is the focus of the new rural reform. However, contractual management rights circulation does not equal privatisation, since collective ownership of rural land is maintained. Moreover, circulation of land use rights has been confined to contractual management rights, and circulation of residential plots and rural land for construction purposes has not yet been clarified. Nor does the new development of the circulation of contractual management rights amount to recognition of a permanent tenancy in which the state nationalises rural land and then grants farmers permanent land use rights. In the decision, contractual management rights will remain unchanged and stable for a long period rather than permanently. The word long (chang) has been used rather than "permanent" (yong). Thus, it is too early to say that the long-term trend of the rural land sys- tem will follow the model of (urban) leasehold as practised in the UK.

The confirmation of the long period of contractual management rights and the encouragement of various experiments with land use rights circulation could be seen as further steps towards the revival of private property in China, as well as the endeavours of the state to fill the gap between law and social practice. However, the extent and effect of such a revival is a complex issue if we consider several questions.

One of the most important questions is how the existing legal system will respond to the new policy, and how the amendments to these laws can be made coherent. The changes to the rural land system again demonstrate that legal reform in China still relies on Party policy, and legal reform usually lags behind policy change. Laws pertaining to property need to conform to Party policy. Such laws involve the Constitution (2004), the Property Law (2007), the Land Administration Law (2004), and so on. Moreover, there are already different experiments with the circulation of land use rights in different localities (see Section IV), and the question is how to deal with these local experiments that contravene the existing legal system. It is especially debatable whether the circulation of rural residential plots such as selling and purchasing "minor property rights" apartments is constitutional. Article 10 of the Constitution (2004) is ambiguous regarding this issue. Although it provides that "land use rights could be transferred," the Constitution does not specify the mechanisms for such transfers.

\section{Conclusion}

This paper has analysed the property market in urban China against the background of broader legal and political transformations, and has reflected upon the meaning of private property and the nature of markets in China. Although the LUR system represents a comprehensive change in the state-owned urban land system, LURs are still allocated administratively to both primary and secondary land use markets. State agencies get LURs free or at low prices and without time limits, but "new economic players" need to bid or negotiate for urban LURs for a fixed period, ${ }^{(6)}$ and they have to cultivate good relationships with agencies such as local governments.

65. On 22 October 2008, the CCP Central Committee declared that "minor property rights" apartments contravened the law, and construction of new apartments should not continue. Although the interests of current purchasers should be protected, the legalisation of the existing apartments is still under review. On this see http://sc.people.com.cn/ news/HTML/2008/10/24/20081024084319.htm (last visited 24 October 2008).

66. See Ho and Lin, "Emerging Land Markets in Rural and Urban China," art. cit., p. 705. 
Far from being a free market, the property market in China has been largely politicised, and the ambiguous and complex relationships between the central government, local governments as entrepreneurs, and non-governmental market players has blurred the boundaries between the public and private sectors as well as the division between the urban and the rural. To characterise the reforms in the area of property law and urban developments as a process of privatisation along the lines of neo-liberal theories would be misleading.

Economic reform from 1978 onwards involved "groping for stones to cross the river," ${ }^{(67)}$ as Deng Xiaoping put it, meaning that it was pragmatic and directed by the "facts" as they seemed at the time without clear guidelines or legal rules, which, usually, lagged behind the pace of economic reform. Pragmatism could and can thus drift into opportunism. This attitude towards reform has shielded it from ideological debates over socialism versus capitalism and has opened up much space for the growth of the private sector. China has become a laboratory in which people (and governments) can experiment. In this sense China has joined the modern world. Everything in society can be commodified and materialised, but only in China's own terms.
The cities have become laboratories for governmental "experiments." Some grassroots initiatives, though, do emerge from the under-defined legal and governmental boundaries. "Minor property rights" apartments flag the complexity and ambiguity that result when time-warped and rigidified urban/rural legal and governmental distinctions become dissolved through the expansion of urban centres into their (juridically rural) peripheries.

$\begin{array}{ll}\text { Glossary } & \\ \text { gong } & \text { 公 } \\ \text { si } & \text { 私 } \\ \text { huji zhidu } & \text { 户籍制度 } \\ \text { xiaochanquan } & \text { 小産權 } \\ \text { xiangchanquan } & \text { 鄉產權 } \\ \text { wuquanfa } & \text { 物權法 } \\ \text { shehuizhuyi gaizao } & \text { 社會主義改造 } \\ \text { danwei } & \text { 單位 } \\ \text { shangpin hua } & \text { 商品化 } \\ \text { huabo } & \text { 劃撥 }\end{array}$

